\title{
Impact of forecasted land use changes on flood risk in the Polish Carpathians
}

\author{
Marcin Szwagrzyk $^{1}$ - Dominik Kaim ${ }^{1}$ - Bronwyn Price ${ }^{2} \cdot$ \\ Agnieszka Wypych ${ }^{1} \cdot$ Ewa Grabska $^{1} \cdot$ Jacek Kozak $^{1}$
}

Received: 7 April 2017/Accepted: 22 May 2018/Published online: 8 June 2018

(C) The Author(s) 2018

\begin{abstract}
Flooding is a major environmental hazard in Poland with risks that are likely to increase in the future. Land use and land cover (LULC) have a strong influencing on flood risk. In the Polish Carpathians, the two main projected land use change processes are forest expansion and urbanization. These processes have a contradictory impact on flood risk, which makes the future impact of LULC changes on flooding in the Carpathians hard to estimate. In this paper, we investigate the impact of the projected LULC changes on future flood risk in the Polish Carpathians for the test area of Ropa river basin. We used three models of spatially explicit future LULC scenarios for the year 2060. We conduct hydrological simulations for the current state and for the three projected land use scenarios (trend extrapolation, 'liberalization' and 'self-sufficiency'). In addition, we calculated the amount of flood-related monetary losses, based on the current flood plain area and both actual and projected land use maps under each of the three scenarios. The results show that in the Ropa river, depending on scenario, either peak discharge decreases due to the forest expansion or the peak discharge remains constant-the impact of LULC changes on the hydrology of such mountainous basins is relatively low. However, the peak discharges are very diverse across sub-catchments within the modeling area. Despite the overall decrease of peak discharge, there are areas of flow increase and there is a substantial projected increase in flood-related monetary losses within the already flood-prone areas, related to the projected degree of urbanization.
\end{abstract}

Keywords LULC · LU modeling · Flood risk assessment · SCS CN · Carpathians

Electronic supplementary material The online version of this article (https://doi.org/10.1007/s11069-0183384-y) contains supplementary material, which is available to authorized users.

Marcin Szwagrzyk

marcin.szwagrzyk@doctoral.uj.edu.pl

1 Institute of Geography and Spatial Management, Jagiellonian University, Gronostajowa 7, 30-387 Kraków, Poland

2 Landscape Dynamics Unit, Swiss Federal Research Institute WSL, Zürcherstrasse 111, 8903 Birmensdorf, Switzerland 


\section{Introduction}

Flood risk is defined as a combination of the probability of a flood event and its negative consequences (UNISDR 2009). Flood risk is considered to be increasing at global and local scales (Kundzewicz et al. 2010) due to climate change and other processes such as the increase of urban area in flood-prone zones (European Parliament 2007; Kundzewicz et al. 2016; Matczak et al. 2017).

Riverine flooding is the biggest natural hazard in Poland (Matczak et al. 2016). In the Polish Carpathians, the most frequent and the most dangerous riverine floods are those caused by rainfall events which last for multiple days in a row, which occur mainly in June and July (Bryndal 2015; Wyżga et al. 2016).

Land use and land cover (LULC) affects both the probability of flood and its consequences in several ways. Land cover affects different elements of the water balance-i.e., evaporation, ground temperatures and interception (Stonestrom et al. 2009). In addition, LULC impacts climate systems, and, in turn, the frequency and characteristics of rainfall (Cornelissen et al. 2013; Boysen et al. 2014; Mitsova 2014). Moreover, there is a direct impact of LULC on the formation of runoff from a particular rainfall event (Tellman et al. 2015). Finally, the land cover in river channels affects the conditions of hydraulic flow and contributes to, for example, woody debris jams on bridges (Stoffel et al. 2016). LULC changes have implications for the consequence component of flood risk through increased development of settlements on flood-prone areas (Kundzewicz et al. 2010).

Numerous studies have considered the general impact of land use change on flooding; however, there are fewer studies of the projected (simulated) impact of future land use on flood risk. Current studies often focus on the impact of forecasted land use on flood consequences, particularly damage in urbanized areas (Chen and Yu 1999; Huong and Pathirana 2013; Mitsova 2014; Choi et al. 2016). Depending on the features of the studied areas and modeled LULC changes, the results were usually similar: urbanization in flood-prone areas causes rapid increase of the projected flood damage. A few studies consider the impact of the projected land cover changes on hydrology and find this impact not significant or even negligible (Altarejos-Garcia et al. 2012; Choi et al. 2016), especially in comparison to other factors such as climate change. In other cases, the projected LULC changes (i.e., urbanization) were shown to cause an increase in peak discharge (Huong and Pathirana 2013; Mitsova 2014). Notably, all the above studies were conducted in urbanized catchments, where further urbanization was the main projected LULC process. So far, less attention has been paid to future flood risk in basins where the main projected LULC processes are related to the transformation of agricultural land uses, e.g., reforestation or urban sprawl.

Poland continues to experience rapid economic and social transitions that affect land use changes (Jepsen et al. 2015) and thereby flood risk. In the mountainous areas of southern Poland, the two main LULC change processes are forest expansion and the development of built-up areas, which includes urban sprawl and the development of second homes (Kaim et al. 2016; Kaim 2017). Price et al. (2017) find that in the coming decades (until 2060) these processes will continue and influenced by past land use patterns, the spatial distribution of changes will diversify.

Forecasted LULC change processes may have contradictory impacts on the formation of runoff. Forest expansion mitigates runoff (e.g., due to retention increase) while urbanization increases it (e.g., due to the increase of impervious areas) (Tellman et al. 2015). Therefore, it is impossible to determine the overall direction of changes in runoff without detailed complex computations. So far, there have been no such analyses for any areas in 
Poland, largely because spatially explicit complex future scenario modeling for large areas has been lacking to date.

Currently, the level of the flood risk in Poland is evaluated by decision makers based on hydraulic and hydrological modeling and spatial analyses (IMGW 2013; Graf 2014). LULC maps are an input to this modeling and analysis. Decisions concerning spatial planning and flood protection means are made based on the flood risk assessment for the current state. These assessments determine flood protection actions, whose implementation will be effective for dozens of years. Therefore, there is a need to include projections of future land use in such analyses.

The aim of the paper is to assess the implications of forecasted LULC changes on future flood risk in the Polish Carpathians under different scenarios. The main objective is to indicate the impact of the forecasted, modeled land cover changes on the peak discharge in a test basin, using hydrological modeling. The second objective is to investigate how the forecasted land use changes would affect the amount of tangible direct flood losses in areas that are already flood prone.

\section{Methods}

This study is based on future land use modeling results for the Polish Carpathians received in the previous work (Price et al. 2017). The results-i.e., the maps for the projected land use scenarios, were used in this study as an input for hydrological modeling and for the spatial analysis of the flood risk.

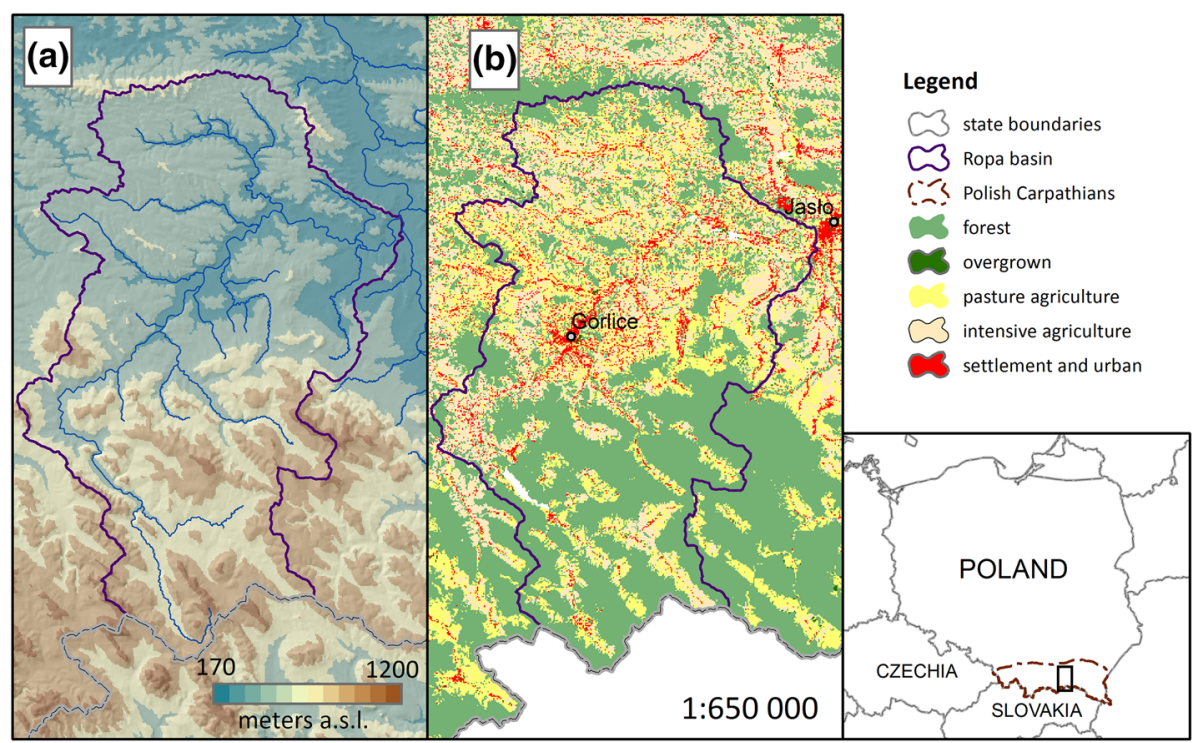

Fig. 1 Study area: a topography and b land use/and cover 


\subsection{Study area}

The study was performed for the test area of the Ropa river basin located in the eastern part of the Polish Carpathians. The basin covers approximately $1000 \mathrm{~km}^{2}$ (Fig. 1). Ropa is the left tributary of the Wisłoka river, with a length of $105 \mathrm{~km}$.

The southern boundary of the basin is also a boundary between Poland and Slovakia. Elevation in the study area varies from 221 to $829 \mathrm{~m}$ above sea level with a mean value of $418 \mathrm{~m}$. Average slope in the area is 4.3 degrees. The largest towns in the study area are Gorlice $(29,500$ inhabitants) and Jasło $(36,600)$. Jasło is located within the Ropa river basin only partly; however, river estuary is located in the city; thus, Ropa has a major impact on the flood risk there.

In the past 150 years, forest cover in the study area increased from $21 \%$ in 1860 to $43 \%$ in 2012 (Kaim et al. 2016). Except for forest expansion, the other important LULC change process in this area is urbanization. Urban population in the two main towns in the area (Jasło and Gorlice combined) increased from 53,000 in 1970 to almost 83,000 in 2014.

Today, the area of settlement covers about $7 \%$ of the Ropa basin. The remaining land is divided into pastures $(26 \%)$ and intensive agriculture (23\%), according to the National Database of Topographic Objects for Poland (Baza Danych Obiektów Topograficznych; BDOT10k) valid for 2013.

Ropa basin is one of the biggest river basins lying entirely in the Polish Carpathians. There is a substantial flood hazard in this area. For example, the city of Jasło was severely flooded in 1997 and 2010 (Rybak 2010) and the floods there are an emergent effect of discharge in three rivers: Ropa, Wisłoka and Jasiołka. Moreover, Ropa basin is generally representative of the Polish Carpathians in terms of land use structure and topography (Table 1).

\subsection{Land use models}

Land use modeling maps of both the current state (2013) and three future land use scenarios (2060) acted as input data to the hydrologic modeling and flood loss assessment. Current land use information for the Polish Carpathians was derived from the national database of topographic objects for Poland (Baza Danych Obiektów Topograficznych; BDOT10k) for the year 2013. Maps of projected future land use under three scenarios were available from existing spatially explicit land use modeling for the Polish Carpathians (Price et al. 2017).

The future land use modeling process is described in detail in Price et al. (2017). The modeling was conducted within the widely used spatially explicit DynaCLUE land use

Table 1 Features of the study area and the Polish Carpathians (BDOT10k)

\begin{tabular}{lll}
\hline & Ropa basin & The Polish Carpathians \\
\hline Total area $\left(\mathrm{km}^{2}\right)$ & 977 & 20,281 \\
Forest area $(\%)$ & 43 & 50 \\
Pasture agriculture area $(\%)$ & 26 & 22 \\
Intensive agriculture area $(\%)$ & 23 & 22 \\
Settlement area $(\%)$ & 7 & 6 \\
Mean slope $\left({ }^{\circ}\right)$ & 4.27 & 4.83 \\
Mean altitude (m a.s.l.) & 418 & 488 \\
\hline
\end{tabular}


allocation framework, which allocates land use change based on scenario defined land use demands, competition amongst land use types and statistical models of suitability for each land use type (Verburg and Overmars 2009; Price et al. 2017).

Price et al. (2017) modeled three scenarios of future land use: trend, liberalization and self-sufficiency; the starting year of the simulation was 2013. The trend scenario assumes extrapolation of observed past changes from the years 1970-2013. The liberalization scenario assumes the acceleration of the rate of land abandonment and urban sprawl, driven mainly by market conditions. Finally, the self-sufficiency scenario assumed a slowdown of land abandonment and spatial concentration of new settlements, due to landscape conservation measures and agricultural subsidies. The modeling area included 194 communes lying entirely within the geographical boundaries of the Polish Carpathians.

Five land use classes were modeled: forest, overgrown, pasture agriculture, intensive agriculture and settlement including urban areas, at a spatial resolution of $100 \mathrm{~m}$. The current land use was derived from the BDOT10k. A set of both biophysical and socioeconomical data were used as explanatory variables to determine suitability for land use classes. Those variables were: slope, distance to roads, mean temperature (correlated with elevation), population density and number of hotels per capita, which indicated the state of tourism development in communes.

Existing demographic and climate projections acted as dynamic drivers in the Price et al. (2017) DynaCLUE modeling. Demographic projections for the years 2010-2050 were sourced from the Central Statistical Office of Poland (GUS 2014) and the climate change projections obtained from the EURO-CORDEX (www.euro-cordex.net) downscaled to $100 \mathrm{~m}$ resolution. The missing 2050-2060 period in demographic projections was filled in by sustaining the 2050 value to 2060 (Price et al. 2017). Future demand for the new settlement areas was computed based on demographic projections-by assigning an amount of new settlement area per person for each of the scenarios.

According to the trend scenario, in 2060 forest covered $48.1 \%$ of the study area (an increase from $43.3 \%$ ) and settlement and urban areas 7.3\% (an increase from 6.8\%). The largest forest expansion and urban sprawl occurred under the liberalization scenario, resulting in coverage of 52.3 and $7.7 \%$ of the study area, respectively. In the self-sufficiency scenario, both forest expansion and urban sprawl were limited resulting in coverage of 44.1 and $7.2 \%$ of the study area, respectively (Fig. 2).

The projected land use changes were unevenly spatially distributed in the test area. In all scenarios, the new settlement and urban areas were concentrated in the already urbanized areas in lower parts of the basin. The new forest areas were located mainly in the hills and remote areas.

\subsection{Hydrologic modeling}

Daily precipitation data from the CARPATCLIM project (http://www.carpatclim-eu.org) were used for hydrological computations which allowed for calculation of 100 years return period values for the area of the Polish Carpathians. These data were downscaled to $100 \mathrm{~m}$ resolution using bilinear interpolation. The remaining data required for hydrologic modeling were derived from the SRTM Digital Elevation Model.

\subsubsection{Hydrologic method}

The SCS CN (Soil Conservation Service Curve Number) method was used to calculate the amount of runoff in Ropa basin sub-catchments. SCS CN is a simple, commonly used 


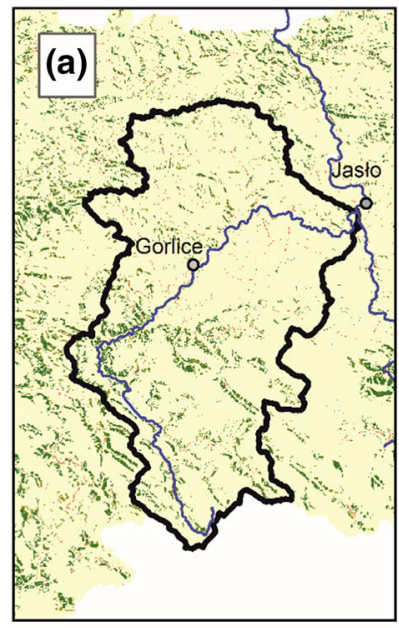

rivers $\square$ Ropa basin

(a)

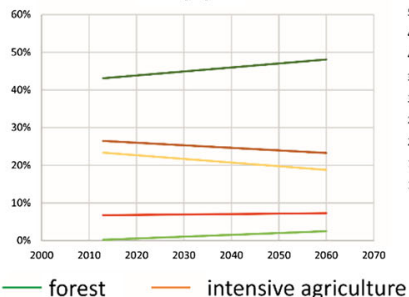

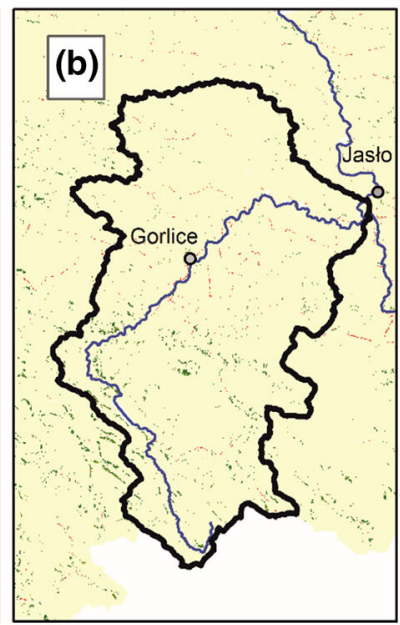

no changes

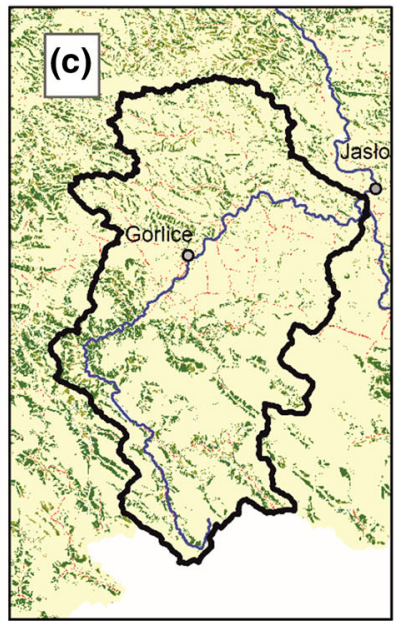

abandoned land new forest

(c)
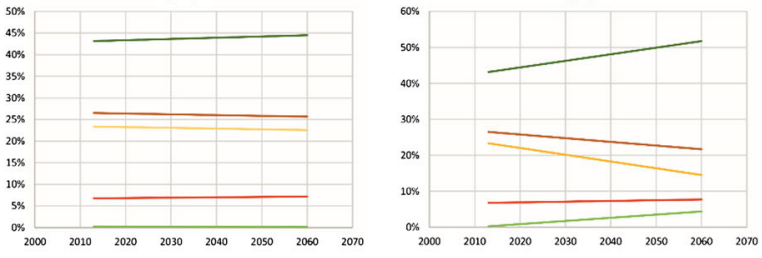

pasture agriculture $\quad$ settlement abandoned land

Fig. 2 Land use modeling results for 2060 in the study area: a trend scenario, b self-sufficiency scenario and c liberalization scenario

method for predicting the amount of runoff from a particular rainfall event (Mishra and Singh 2003; Soulis and Valiantzas 2012). The amount of runoff from rainfall depends on land cover type, soil group and morphological catchment characteristics. A CN of 100 indicates that all the rainfall is transformed into runoff and a $\mathrm{CN}$ of 0 means that there is no runoff. The value of the $\mathrm{CN}$ parameter can be computed empirically or can be adjusted from fixed tables, according to the sub-catchment land cover and soil characteristics. The SCS CN method is used for flood protection concept works in Poland (RZGW 2010).

\subsubsection{Model development}

We developed hydrologic models in HEC-HMS (Hydrologic Engineering Center-Hydrologic Modeling System), an open source modeling framework developed by the US Army Corps of Engineering (Feldman 2000). The model for the Ropa river basin consisted of 120 sub-catchments delineated using the SRTM Digital Elevation Model. The values of the following parameters were defined for each sub-catchment: area, mean slope, hydraulic length, precipitation time series and a $\mathrm{CN}$ value. 


\subsubsection{Input data for modeling}

$\mathrm{CN}$ values were calculated for each sub-catchment based on the land use maps for both the current state and each of the three future (year 2060) land use scenarios. Due to the high cost of detailed soil maps for the whole area and a lack of detailed soil maps for forests (which cover almost 50\% of the modeled area), no fine-scale soil map was used in assigning the $\mathrm{CN}$ values. Based on the analysis of the broad-scale soil map (Brożek 2013), we assigned moderate "B" value of soil moisture retention for all of the sub-catchments (Feldman 2000). We adjusted CN values for different land use classes from BDOT10k, and subsequently calculated mean $\mathrm{CN}$ values for five modeled land use classes (Table 2). The lag time parameter (minutes) for each sub-catchment was calculated based on the $\mathrm{CN}$ value and on the catchment slope and hydraulic length, which were derived from the DEM.

As we were interested in assessing the sensitivity of the hydrological model only to land use change parameters, we have not taken climate change into consideration in the hydrological model, though it was considered in the land use model. One of the main reasons to omit the impact of the climate change projections on our hydrological modeling is that including these projections in simulations would make it difficult to separate the impact of the future land use change on flood. Climate change impact is significantly more severe in comparison to the land use changes impact. Therefore, for all the scenarios-both for the current state land use and for the future land use, we assumed a precipitation equivalent to an actual 100 year return period precipitation-which reflects a "medium hazard" probability for flood protection concepts in Poland (RZGW 2010; Graf 2014).

The amount of precipitation in an event with a 100 year return period in the study area varied from 69 to $99 \mathrm{~mm}$. Based on the spatial and statistical analysis of the precipitation map, the sub-catchments in the Ropa basin were classified into four different precipitation regions. A hyetograph was calculated for each region based on the amount of 100 years return period rainfall and rainfall distribution according to the DVWK (de: Deutscher Verband für Wasserwirtschaft und Kulturbau) (Ott and Uhlenbrook 2004; Barszcz 2012).

Table 2 Land use classes and assigned CN values source: BDOT10k

\begin{tabular}{|c|c|c|}
\hline Land use class & Description & $\begin{array}{l}\mathrm{CN} \\
\text { value }\end{array}$ \\
\hline Forest & Forest including damaged forest areas, copse, wooded area & 60 \\
\hline Overgrown & $\begin{array}{l}\text { Shrubs, small woodlots on meadows, pastures and other abandoned agricultural } \\
\text { lands }\end{array}$ & 62 \\
\hline Grazing areas & Meadows, farm pastures & 68 \\
\hline $\begin{array}{l}\text { Intensive } \\
\text { agriculture }\end{array}$ & $\begin{array}{l}\text { Arable land, intensive orchards, field fruit trees, vineyards, plantations, plant } \\
\text { nurseries }\end{array}$ & 72 \\
\hline $\begin{array}{l}\text { Settlement and } \\
\text { urban }\end{array}$ & $\begin{array}{l}\text { One and many family houses with surroundings, blocks of flats, industrial and } \\
\text { commercial buildings with surroundings, other buildings, residential } \\
\text { complexes, housing estates, transport and communication areas, sport and } \\
\text { recreational facilities, parks, public complexes, hospital complexes, } \\
\text { cemeteries, camping areas, roads, railroads, airports, squares, garbage dumps, } \\
\text { excavation grounds, quarries and mines, other industrial and storage areas }\end{array}$ & 90 \\
\hline
\end{tabular}




\subsubsection{Hydrologic computations}

Four hydrological simulations (one for the current state and one for each of the three scenarios) were run with different sets of $\mathrm{CN}$ parameters and otherwise with all other simulation parameters remaining constant. These simulations resulted in discharge curves for each scenario and the current state.

\subsection{Flood losses analysis}

The map of the current floodplain area was used for the assessment of flood losses. It was derived from flood risk and flood hazard maps developed by the Polish Institute of Meteorology and Water Management PIB (Kęsy and Włodarczyk 2014; KZGW 2014, 2015).

A series of spatial analyses of flood losses was conducted for the current floodplain zone under both current and forecasted land use maps for 2060. We calculated the sum of the direct economic tangible flood losses in the simplest manner possible-as a binary function of whether a terrain is flooded or not (Hammond et al. 2015).

A monetary value was assigned to each hectare of a particular land use class, based on the standard Polish methodology (KZGW 2014) and expressed in Euro (EUR) (Table 3). We aggregated values for several settlement and infrastructure land use classes into one mean value for the modeled "settlement and urban" class. Due to the lack of precise flood depth maps and the low spatial resolution of our land use maps, we assumed the worst case scenario-i.e., all the flooded area has above $0.5 \mathrm{~m}$ of water depth. The purpose of this assumption was to indicate the highest likely flood risk.

\section{Results}

\subsection{Hydrologic modeling results}

Changes in the $\mathrm{CN}$ values were unevenly spatially distributed, according to the distribution of the forecasted land use changes. Changes of the $\mathrm{CN}$ values had direct impact on the computed peak discharges.

The peak discharge value in the Ropa river estuary for the current state was 740 cubic meters per second. In all the scenarios, the discharge value decreased: to 737 in the selfsufficiency scenario, to 720 in the trend scenario and to 705 in the liberalization scenario. However, even under the liberalization scenario, for which the largest decrease was observed, the discharge was only decreased from the current value by $5.5 \%$. At the sub-

Table 3 Monetary losses assinged to land use changes

\begin{tabular}{ll}
\hline Land use class & Amount (EUR/ha) \\
\hline Forest & 18.7 \\
Overgrown & - \\
Pasture agriculture & 157.2 \\
Intensive agriculture & 333.2 \\
Settlement and urban & 634507.7 \\
\hline
\end{tabular}


catchment level, there was a considerable spatial heterogeneity in peak discharge and the effects of the different land use change scenarios (Fig. 3).

The highest decrease in peak discharge occurred in the liberalization scenario in the Potok Dragowski sub-catchment, located in the western part of the study area. Here, peak discharge shrank from 7.9 to 6.2 cubic meters per second, which is a $21 \%$ decrease. This decrease of discharge was caused by forest expansion, this sub-catchment located in the remote, hilly area of the basin, where forest is projected to increase from 22 to $49 \%$ under the liberalization scenario.

Peak discharge decreased substantially (by more than 10\%) in several similar subcatchments, both in the liberalization (20) and trend (12) scenarios. Due to the mitigation of land abandonment in the self-sufficiency scenario, in all sub-catchments in the study area peak discharge either remained constant or decreased only slightly (up to $3 \%$ ).

The biggest increase in discharge occurred under the liberalization scenario in a subcatchment located in the suburbs of the town Gorlice. Here, modeled peak discharge increased from 1.9 to 2.0 cubic meters per second, following the expansion of settlement and urban areas in this sub-catchment from 20 to $26 \%$ of the area. Increases in peak discharge occurred in 13 sub-catchments in the liberalization scenario (with a mean increase of 3.4\%), 9 sub-catchments in the trend scenario (mean increase was 3.5\%) and 31 sub-catchments in the self-sufficiency scenario, but with a mean value of increase of just $2.3 \%$.

\subsection{Flood losses results}

The floodplain area for a 100-year return period flood in the Ropa basin is 2018 hectares. Since changes in peak discharge in the modeled land use scenarios were only minor (up to approx. $5 \%$ of the overall peak discharge decrease), the current state flood plain was

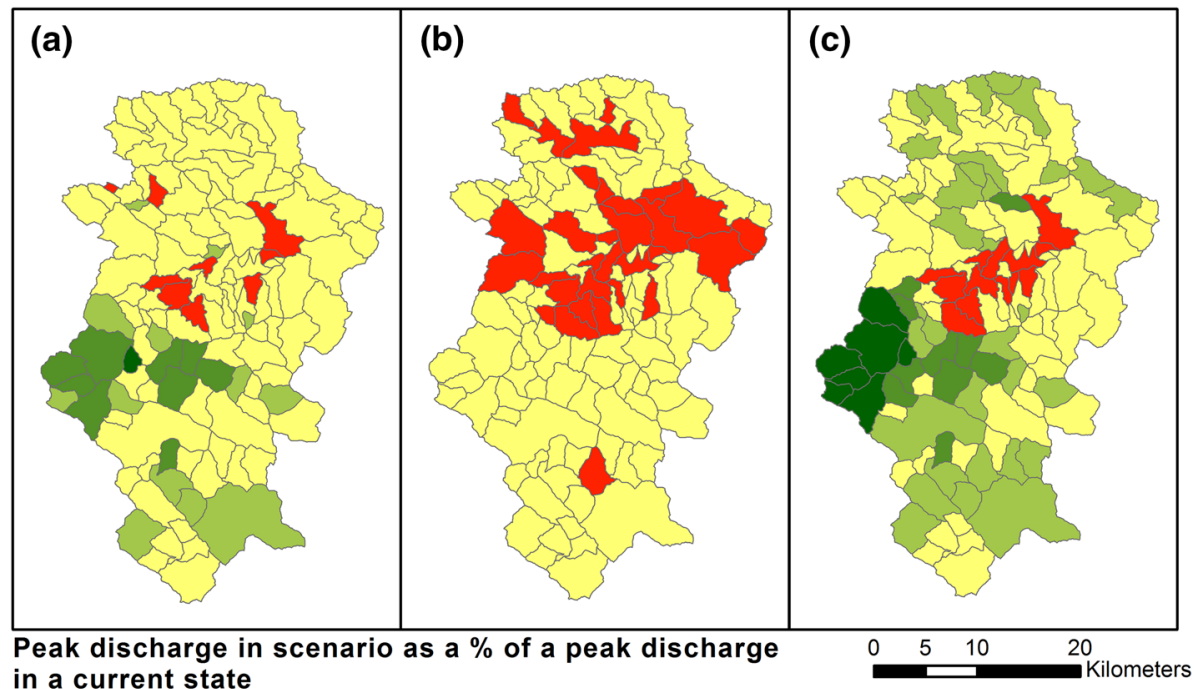
in a current state

$<85 \% \square \quad 85-90 \% \square 90-95 \% \square 95-100 \% \square>100 \%$

Fig. 3 Changes in peak discharges: a trend scenario, b self-sufficiency scenario and c liberalization scenario 
assumed for the future flood losses analyses. Therefore, we did not investigate the impact of the modeled peak discharge on the range of floodplain area. Within the floodplain area, the forest share in a trend scenario was $21 \%$ (an increase from $18 \%$ in the current state), and settlement $10 \%$ (an increase from $8 \%$ ), 21 and $11 \%$, respectively, in the self-sufficiency scenario and, with the largest share of forest and settlement in the floodplain area, 22 and $14 \%$ under the liberalization scenario.

Under the liberalization scenario, the value of flood losses for a 100-year flood reached 177.03 million EUR, approximately 65\% more than under the current state (107.23 million EUR). Economic flood losses were also greater in the other two future land use scenarios than in the current state: 125.63 million for the trend scenario and 147.21 million for the self-sufficiency scenario (Fig. 4).

\section{Discussion}

This study presents an application of a complex spatially explicit land use modeling to a real-world problem with direct implications for spatial management and flood risk assessment. Our results are similar to many studies considering LULC changes and their impact on runoff formation. Depending on the land use scenario and analyzed subcatchments, the results are either negligible as, for instance, in Choi et al. (2016), or they show an increase of hydrological flows in urbanized catchments, as in Huong and Pathirana (2013), Mitsova (2014), Löschner et al. (2016). On the other hand, a decrease in flows is projected in many of the forested sub-catchments of the study area in all the modeled scenarios.

Models of future land use have an inherent level of uncertainty and should be considered rather a tool which allows for understanding of processes than one with which to make precise predictions (Lars Berglund 2014). For instance, locations forecasted to be subject to urbanization by the land use models used in the study should be interpreted as indications of areas most suitable for future settlement development, and not precise

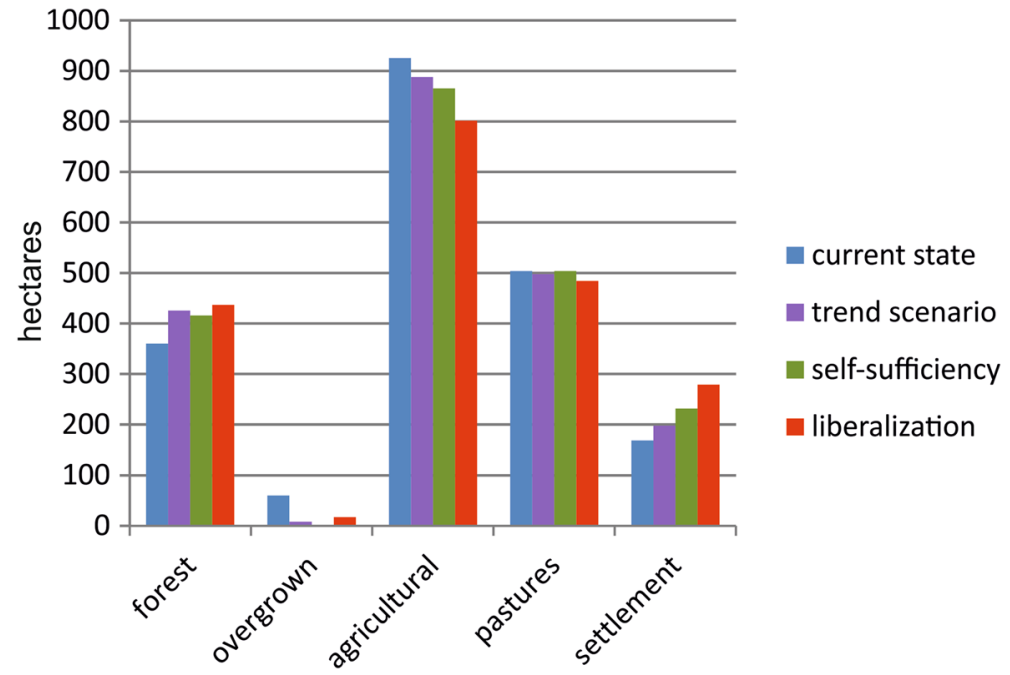

Fig. 4 Area of flooded land use classes 
locations of future change. Nevertheless, the analysis revealed a major increase in the economic costs of floods due to a likely general pattern of settlement encroachment into flood-prone areas, similar to the findings of Chen and Yu (1999), Choi et al. (2016) and Huong and Pathirana (2013).

This situation arises largely because flood-prone areas, being flat and situated along valleys, tend to share characteristics with areas defined as highly suitable for settlement development. Increased settlement development in flood-prone areas has been reported in Poland in recent years (Matczak et al. 2016). These results demonstrate the need for a more strict spatial planning policy and necessity of implementing building restriction zones in the known floodplain areas (Beckers et al. 2013). This study shows that the ongoing and projected forest expansion in the Polish Carpathians, despite its scale and associated reduction of flood risk in remote sub-basins, will not efficiently mitigate the flood risk in urbanized areas. Since the study area is a typical for the Polish Carpathians, this method is appropriate for application to other Carpathians basins.

Due to the data availability limitations, our approach required several simplifying assumptions. In the SCS Curve Number Method (Mishra and Singh 2003), usually dozens of anthropogenic land use class are distinguished with $\mathrm{CN}$ values for ranging from 65 to 95. However, the land use scenario models available for the hydrologic and hazard analyses in our study were limited to 5 land use classes, including one single 'settlement' class which covers all the infrastructure and built-up areas to which we assigned a $\mathrm{CN}$ value of 90. Furthermore, no within-type land use modifications (e.g., increase of impervious surfaces in the areas which lie within the urban land use classes) were included in the land use modeling. Such modifications can be important for flood formation. In addition, the spatial resolution of $100 \mathrm{~m}$ would not have allowed for modeling the precise location of within urban area sub-category LULC changes (Canters et al. 2007). Therefore, some aspects of the impact of urbanization (such as within LU class modifications) on the formation of runoff could not be taken into account. Despite the spatial concentration of new urban areas, our results find the overall impact of urbanization on peak discharge to be rather moderate (even in the urbanized catchments) and, at the scale of the whole basin, this impact is completely mitigated by concurrent forest expansion. However, there is a considerable spatial heterogeneity in modeled peak discharge across the study area, with several areas, in particular small sub-catchments, showing the projected increase of the flood risk. These results demonstrate the necessity of using an appropriate spatial scale and areal unit for assessing the studied phenomena (Openshaw 1984). Furthermore, it should be emphasized that the study did not include the impact of the future land use on water balance elements such as evaporation and interception, which may also affect the flood risk in the basin (Stonestrom et al. 2009).

In this study we used methods and input data suitable for modeling large riverine flood events, while urbanization is often responsible for small, frequent floods (Hollis 1975; Kundzewicz et al. 2013). These two types of flood are different in nature and there are appropriate methods for assessing each of them (Hammond et al. 2015). However, riverine floods occurring on large rivers after a couple of days with rain are still the most dangerous floods in the Polish Carpathians (Bryndal 2015). Therefore, flood risk assessments based on the SCS CN method can form a basis for the planning of flood protection actions and spatial planning policy in the Polish Carpathians. 


\section{Conclusions}

Across the study area, the forecasted expansion of forest extent is likely to mitigate the overall effects of urbanization on flood peak discharge to some extent and slightly reduce the peak discharge across the whole Ropa basin. However, despite the scale of land abandonment and secondary succession processes in the study area, the mitigation effect of the forest expansion on the peak discharges is a very small in the liberalization scenario (approximately 5\% decrease in peak discharge) and in the remaining two scenarios it is negligible.

Due to the spatial heterogeneity of forecasted land use modeling changes, despite the overall decrease of the peak discharges, the forecasted LULC changes will cause an increase in flows (up to 5\%) in some urbanized basins. There is also a forecasted increase of urban areas in the current flood-prone zones in every modeled land use scenario, which results in substantial increase of the estimated economic losses due to flood.

Our results demonstrate that further more detailed studies on the impact of the LULC changes on flood hazard are necessary, especially in urbanized areas. Such studies would be invaluable in spatial planning and can indicate areas which are currently or potentially (due to increase in flows caused by land cover changes) flood prone and are also likely to be subject to future settlement development. Such areas should be of special consideration in the formation of spatial planning policy to avoid economic losses in the future.

Acknowledgements Research carried out within the FORECOM project (Forest cover changes in mountainous regions-drivers, trajectories and implications, PSRP 008/2010), supported by a grant from Switzerland through the Swiss contribution to the enlarged European Union.

Open Access This article is distributed under the terms of the Creative Commons Attribution 4.0 International License (http://creativecommons.org/licenses/by/4.0/), which permits unrestricted use, distribution, and reproduction in any medium, provided you give appropriate credit to the original author(s) and the source, provide a link to the Creative Commons license, and indicate if changes were made.

\section{References}

Altarejos-Garcia L, Martinez-Chenoll ML, Escuder-Bueno I, Serrano-Lombillo A (2012) Assessing the impact of uncertainty on flood risk estimates with reliability analysis using 1-D and 2-D hydraulic models. Hydrol Earth Syst Sci 16:1895-1914. https://doi.org/10.5194/hess-16-1895-2012

Barszcz M (2012) Znormalizowane rozkłady warstwy opadu w czasie trwania deszczy na obszarze zlewni doświadczalnej w Warszawie 2012:27-38

Beckers A, Dewals B, Erpicum S et al (2013) Contribution of land use changes to future flood damage along the river Meuse in the Walloon region. Nat Hazards Earth Syst Sci 13:2301-2318. https://doi.org/10. 5194/nhess-13-2301-2013

Boysen LR, Brovkin V, Arora VK et al (2014) Global and regional effects of land-use change on climate in 21st century simulations with interactive carbon cycle. Earth Syst Dyn 5:309-319. https://doi.org/10. 5194/esd-5-309-2014

Brożek S (2013) Gleby w środowisku przyrodniczym i krajobrazach Europy

Bryndal T (2015) Local flash floods in Central Europe: a case study of Poland. Nor J Geogr 69:288-298. https://doi.org/10.1080/00291951.2015.1072242

Canters F, Van De Voorde T, Batelaan O et al (2007) Measuring and modeling urban dynamics: Impact on quality of life and hydrology objectives and methodology. Int Geosci Remote Sens Symp. https://doi. org/10.1109/IGARSS.2007.4423220

Chen Y, Yu B (1999) Impacts of climate and land-use changes on floods in an urban catchment in southeast Queensland, Australia. Griffith School of Engineering, Griffith University, Nathan, pp 1-7

Choi W, Pan F, Wu C (2016) Impacts of climate change and urban growth on the streamflow of the Milwaukee River. Reg Environ Change. https://doi.org/10.1007/s10113-016-1083-3 
Cornelissen T, Diekkrüger B, Giertz S (2013) A comparison of hydrological models for assessing the impact of land use and climate change on discharge in a tropical catchment. J Hydrol 498:221-236. https://doi. org/10.1016/j.jhydrol.2013.06.016

European Parliament (2007) Directive 2007/60/EC of the European Parliament and of the council of 23 October 2007 on the assessment and management of flood risks

Feldman AD (2000) Hydrologic modeling system HEC-HMS, technical reference manual 145

Graf R (2014) Mitigation of flood risk in Poland [Mitygacja ryzyka powodziowego w Polsce]. In: Monografie komitetu gospodarki wodnej PAN

GUS (2014) Prognoza ludności na lata 2014-2050

Hammond MJ, Chen AS, Djordjevic S et al (2015) Urban flood impact assessment: a state-of-the-art review. Urban Water J 12:14-29. https://doi.org/10.1080/1573062X.2013.857421

Hollis GE (1975) The effect of urbanization on floods of different recurrence interval. Water Resour Res 11:431-435. https://doi.org/10.1029/WR011i003p00431

Huong HTL, Pathirana A (2013) Urbanization and climate change impacts on future urban flooding in Can Tho city, Vietnam. Hydrol Earth Syst Sci 17:379-394. https://doi.org/10.5194/hess-17-379-2013

IMGW (2013) Metodyka opracowania planów zarządzania ryzykiem powodziowym dla obszarów dorzeczy i regionów wodnych - Załącznik do Raportu ze zmian do „Metodyki PZRP”

Jepsen MR, Kuemmerle T, Müller D et al (2015) Transitions in European land-management regimes between 1800 and 2010. Land Use Policy 49:53-64. https://doi.org/10.1016/j.landusepol.2015.07.003

Kaim D (2017) Land cover changes in the Polish Carpathians based on repeat photography. Carpathian J Earth Environ Sci 12:485-498

Kaim D, Kozak J, Kolecka N et al (2016) Broad scale forest cover reconstruction from historical topographic maps. Appl Geogr 67:39-48. https://doi.org/10.1016/j.apgeog.2015.12.003

Kęsy R, Włodarczyk A (2014) Główne założenia metodyk dotyczących opracowania map zagrożenia powodziowego

Kundzewicz ZW, Lugeri N, Dankers R et al (2010) Assessing river flood risk and adaptation in Europereview of projections for the future. Mitig Adapt Strateg Glob Change 15:641-656. https://doi.org/10. 1007/s11027-010-9213-6

Kundzewicz ZW, Kanae S, Seneviratne SI et al (2013) Flood risk and climate change: global and regional perspectives. Hydrol Sci J 59:1-28. https://doi.org/10.1080/02626667.2013.857411

Kundzewicz ZW, Krysanova V, Dankers R et al (2016) Differences in flood hazard projections in Europetheir causes and consequences for decision making. Hydrol Sci J. https://doi.org/10.1080/02626667. 2016.1241398

KZGW (2014) Raport z wykonania map zagrożenia powodziowego

KZGW (2015) Hydroportal publikujący mapy zagrożenia powodziwoego i mapy ryzyka powodziowego w formacie PDF. http://www.powodz.gov.pl/www/

Lars Berglund (2014) Review of land-use models

Löschner L, Herrnegger M, Apperl B et al (2016) Flood risk, climate change and settlement development: a micro-scale assessment of Austrian municipalities. Reg Environ Change. https://doi.org/10.1007/ s10113-016-1009-0

Matczak P, Lewandowski J, Choryński A et al (2016) Flood risk governance in Poland: looking for strategic planning in a country in transition (report D3.6). Utrecht

Matczak P, Lewandowski J, Choryński A et al (2017) Doing more while remaining the same? Flood risk governance in Poland. J Flood Risk Manag 10:10. https://doi.org/10.1111/jfr3.12300

Mishra SK, Singh VP (2003) Soil conservation service curve number (SCS-CN). Methodology. https://doi. org/10.1007/978-94-017-0147-1

Mitsova D (2014) Coupling land use change modeling with climate projections to estimate seasonal variability in runoff from an urbanizing catchment near Cincinnati, Ohio. ISPRS Int J Geo-Inf 3:1256-1277. https://doi.org/10.3390/ijgi3041256

Openshaw S (1984) The modifiable area unit problem. Concepts Tech Mod Geogr 38:1-41

Ott B, Uhlenbrook S (2004) Quantifying the impact of land-use changes at the event and seasonal time scale using a process-oriented catchment model. Hydrol Earth Syst Sci 8:62-78. https://doi.org/10.5194/ hess-8-62-2004

Price B, Kaim D, Szwagrzyk M et al (2017) Legacies, socio-economic and biophysical processes and drivers: the case of future forest cover expansion in the Polish Carpathians and Swiss Alps. Reg Environ Change. https://doi.org/10.1007/s10113-016-1079-z

Rybak T (2010) Informacja o klęsce powodzi. In: Raport o stanie środowiska 2010, pp 149-157

RZGW (2010) Model hydrologiczny opad-odpływ 
Soulis KX, Valiantzas JD (2012) SCS-CN parameter determination using rainfall-runoff data in heterogeneous watersheds-the two-CN system approach. Hydrol Earth Syst Sci 16:1001-1015. https://doi.org/ 10.5194/hess-16-1001-2012

Stoffel M, Nied T, Ruiz-Villanueva V et al (2016) Flood risk in the Upper Vistula Basin. Springer, New York, pp 23-38. https://doi.org/10.1007/978-3-319-41923-7

Stonestrom DA, Scanlon BR, Zhang L (2009) Introduction to special section on impacts of land use change on water resources. Water Resour Res 45:1-3. https://doi.org/10.1029/2009WR007937

Tellman B, Saiers JE, Cruz OAR (2015) Quantifying the impacts of land use change on flooding in datapoor watersheds in El Salvador with community-based model calibration. Reg Environ Change. https:// doi.org/10.1007/s10113-015-0841-y

UNISDR (2009) 2009 UNISDR Terminology on disaster risk reduction. International strategy for disaster reduction, pp 1-30. https://www.unisdr.org/we/inform/publications/7817

Verburg PH, Overmars KP (2009) Combining top-down and bottom-up dynamics in land use modeling: exploring the future of abandoned farmlands in Europe with the Dyna-CLUE model. Landsc Ecol 24:1167-1181. https://doi.org/10.1007/s10980-009-9355-7

Wyżga B, Kundzewicz ZW, Ruiz-Villanueva V, Zawiejska J (2016) Flood generation mechanisms and changes in principal drivers. In: Kundzewicz Z, Stoffel M, Niedźwiedź T, Wyżga B (eds) Flood Risk in the Upper Vistula Basin. GeoPlanet: Earth and Planetary Sciences. Springer, Cham, pp 55-75. https:// doi.org/10.1007/978-3-319-41923-7 